\title{
Cumberland River Resource Stewardship and Protection: Managing the Cumberland River and the Land Between the Lakes Landscapes
}

\author{
Kenneth R. Olson \\ College of Agricultural, Consumer, and Environmental Sciences, University of Illinois, Urbana, USA \\ Email: krolson@illinois.edu
}

How to cite this paper: Olson, K.R. (2021) Cumberland River Resource Stewardship and Protection: Managing the Cumberland River and the Land Between the Lakes Landscapes. Journal of Water Resource and Protection, 13, 92-111.

https://doi.org/10.4236/jwarp.2021.132006

Received: January 18, 2021

Accepted: February 16, 2021

Published: February 19, 2021

Copyright $\odot 2021$ by author(s) and Scientific Research Publishing Inc. This work is licensed under the Creative Commons Attribution International License (CC BY 4.0).

http://creativecommons.org/licenses/by/4.0/

\begin{abstract}
Cumberland River formed on Cumberland Plateau by confluence of the Poor and Clover forks in Harlan county, Kentucky and loops south through northern Tennessee. It joints the Ohio River at Smithland, Kentucky. The Cumberland River is $1107 \mathrm{~km}$ long and has a drainage area of $46,830 \mathrm{~km}^{2}$. The Cumberland crosses a highland bench in Cumberland Plateau and flows in a gorge between 90 - $120 \mathrm{~m}$ cliffs. The Cumberland Falls is $20.7 \mathrm{~m}$ high. The river enters the central limestone basin of Tennessee, turning north, crosses the plain of western Kentucky to Ohio River at Smithland, Kentucky and at one point it is less than $3 \mathrm{~km}$ from Tennessee River. The Cumberland River had a long history of transporting furs, canoes, guns, armies, settlers, coal products and manufactured goods in the 1700s and 1800s. Three separate forks (Martin's Fork, Clover Fork, and Poor Fork) flow out of the Appalachian Mountains in southeast Kentucky near the Virginia border to form the headwaters of the Cumberland River near Harlan, Kentucky. Steamboat traffic on the Cumberland River increased substantially in the 1800s as expanding coal fields, stone quarries and Tennessee produce began to be shipped throughout the region. The Cumberland River was surveyed during this period and between 1832 and 1838 Congress appropriated $\$ 155,000$ for improving commercial navigation. With this infusion of money the United States Army Corps of Engineers (USACE) could clear the river of snags and build wing dams to deepen the channel. A $1060 \mathrm{~km}$ Cumberland River regional trail system, similar to the Tennessee River regional trail system under development, is needed to promote recreational tourism and increase use of the Cumberland River and basin. The primary objectives are: 1) to document how the landscape and geological resources of the Cumberland River have contributed to the successful water resource and economic development of a historic region in North America, 2) to identify future risks to the natural and
\end{abstract}


environmental resources, 3) create a regional trail system with community access points and 4) create generations of people who care about the environmental stewardship and protection of the river and landscape resources.

\section{Keywords}

Barkley Lake, Tennessee Valley Authority, TVA

\section{Introduction}

During the American Civil War, Kentucky and Tennessee were critical border states (Figure 1). Both the Union and Confederate armies sought to control river traffic to ensure troops and supplies reached strategic locations [1]. Fort Donelson (Figure 2) was built on the Cumberland River by the Confederates 80 $\mathrm{km}$ upstream from its confluence with the Ohio River in order to protect Nashville (Figure 3) from Union forces approaching by river. However, the upper Cumberland (Figure 4) was not easy to defend and the fort was captured in February, 1862, by Union troops using gun boats made at Mounds City, Illinois. Fort Donelson National Military Park (Figure 5), in northern Tennessee on the Cumberland River commemorates the 1862 American Civil War battle which opened up the adjacent Cumberland River for Union troops to advance. As the Civil War came to an end in 1865, the region began to rebuild and redirect wartime resources including coal (Figure 6) into industries that would bring economic and social prosperity. The timber industry boomed as logs from the hardwood forests of the Appalachian Mountains and foothills were cut and transported

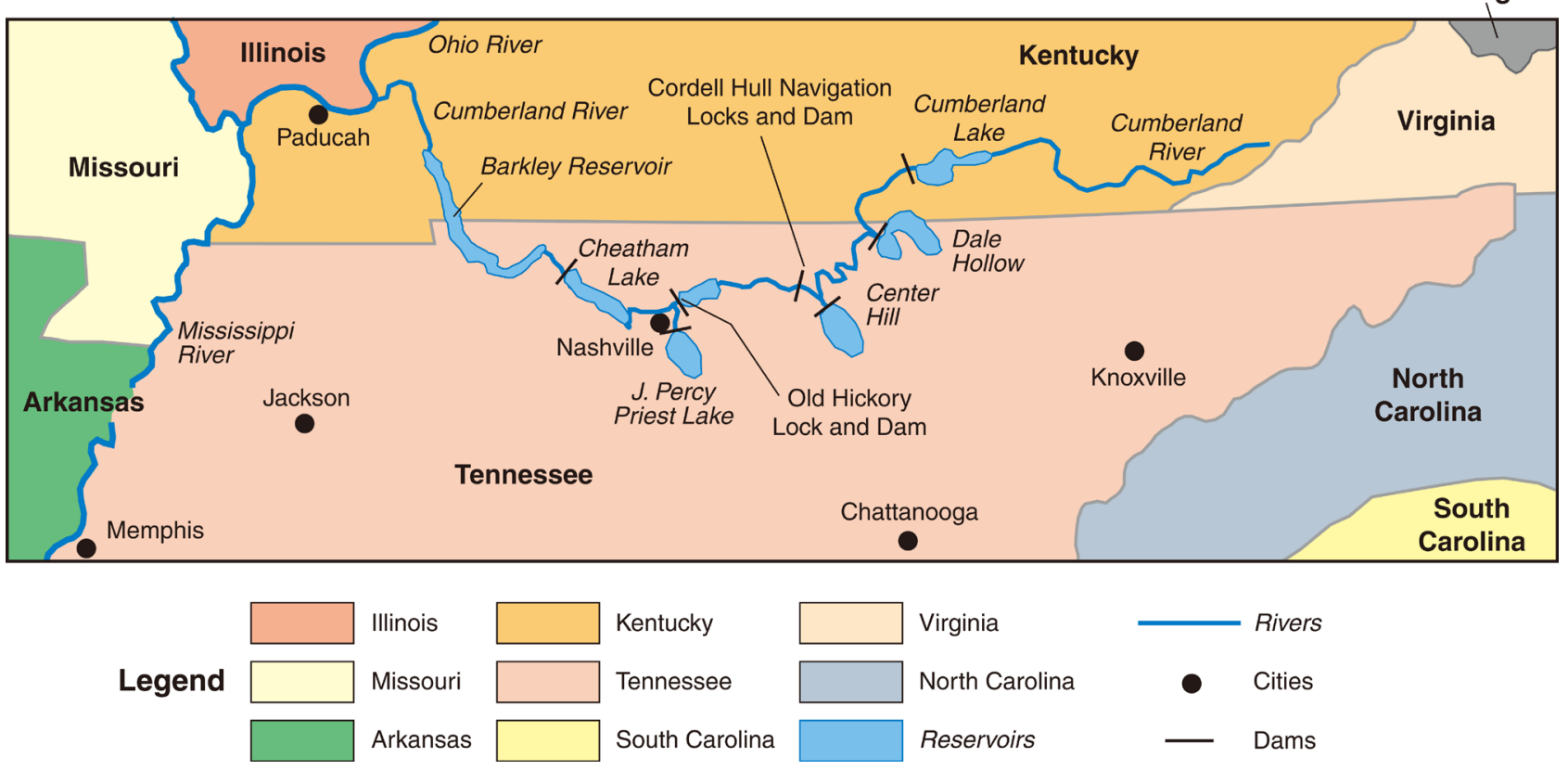

Figure 1. Cumberland River Watershed in Tennessee and Kentucky. Map by Mic Greenberg. 


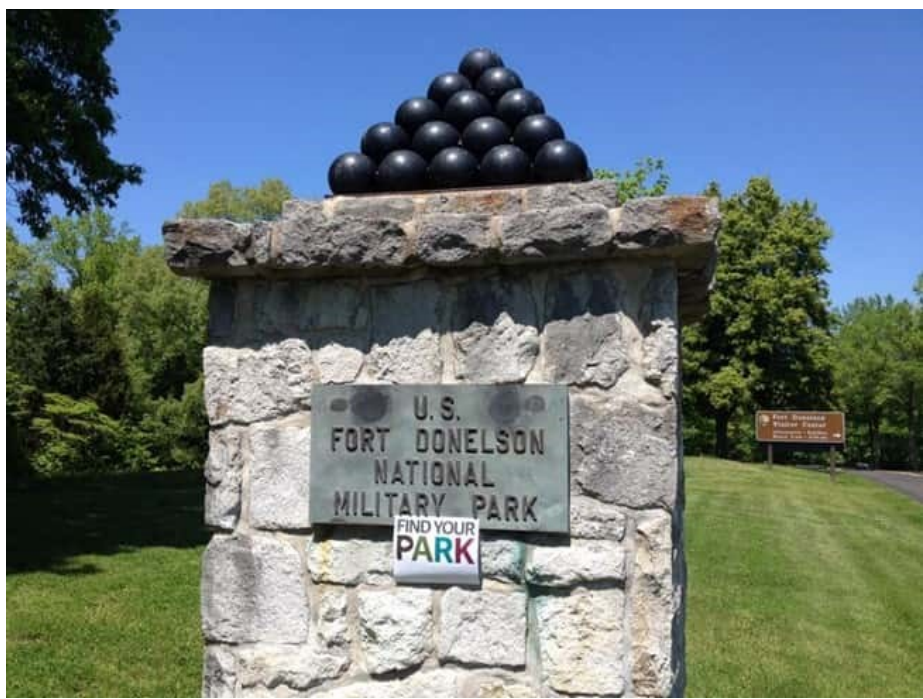

Figure 2. Fort Donelson Military Park sign with cannon balls on top.

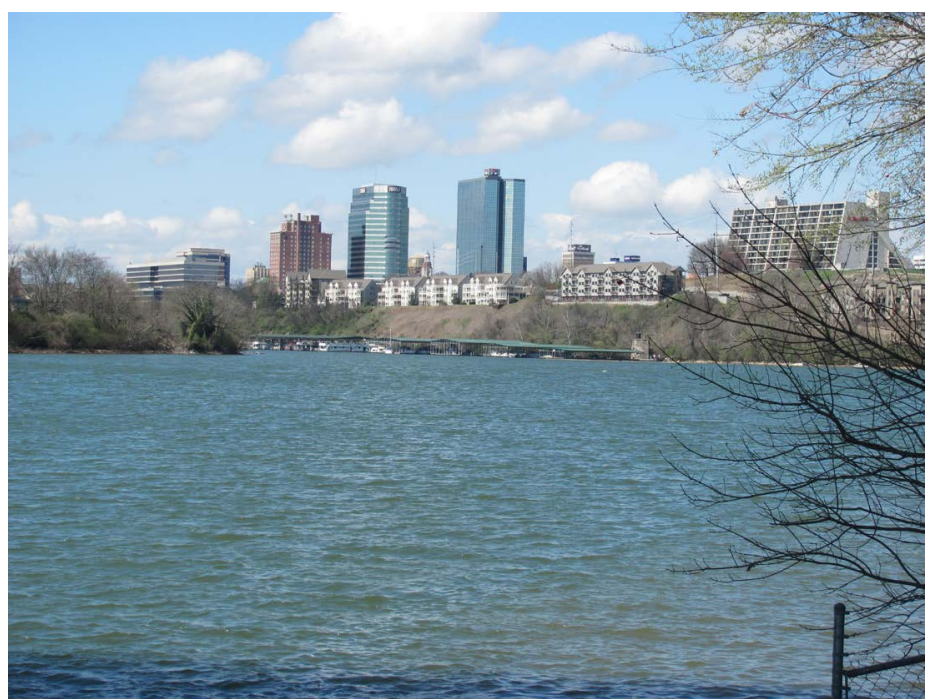

Figure 3. Nashville located on the Cumberland River.

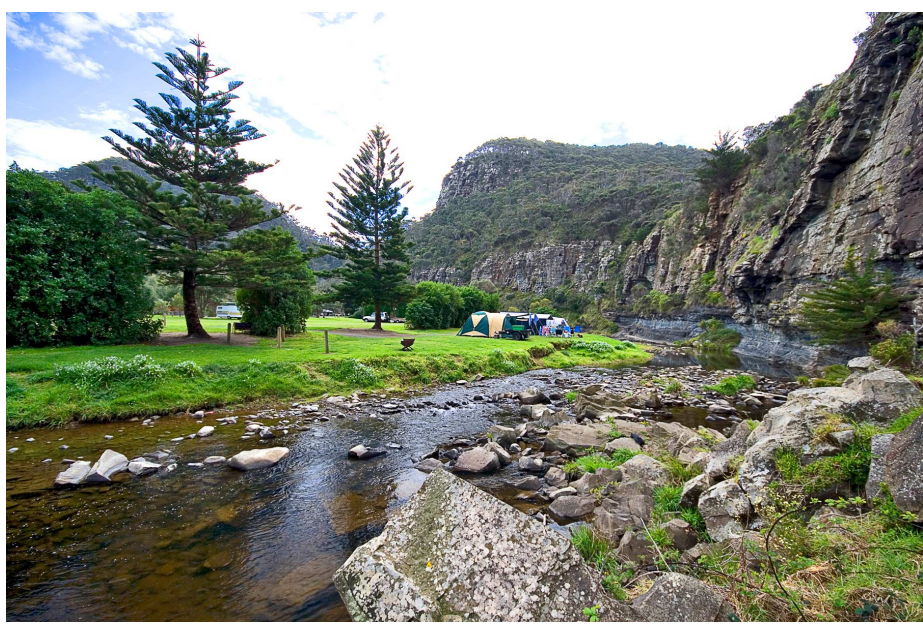

Figure 4. The headwaters of the Cumberland River in the mountains of Kentucky. 


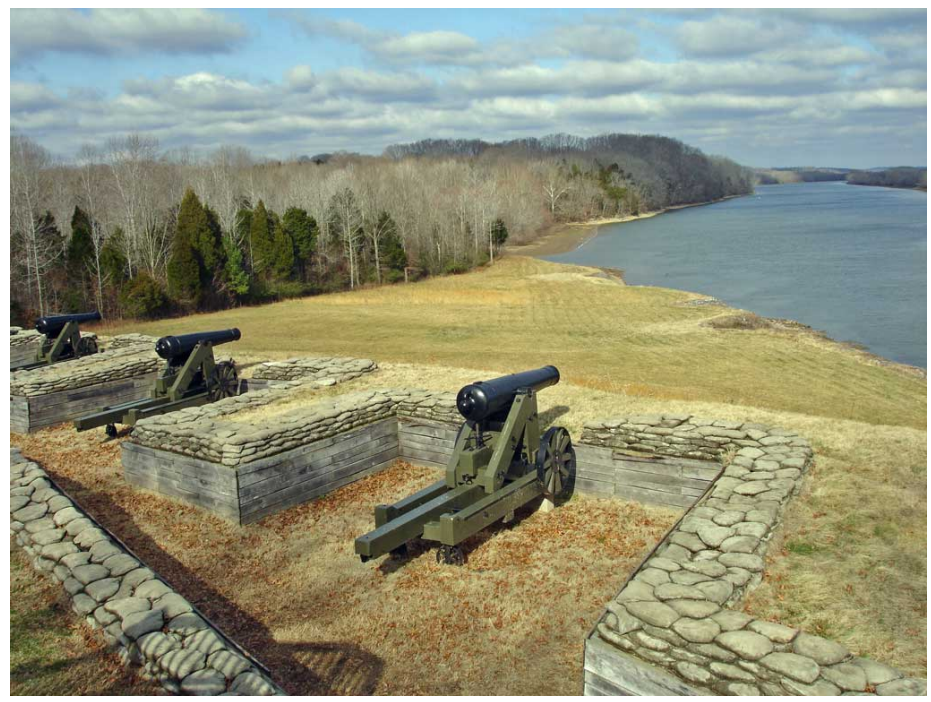

Figure 5. Fort Donelson cannons aimed at the Cumberland River to stop the Union troops from advancing to Nashville during the Civil War.

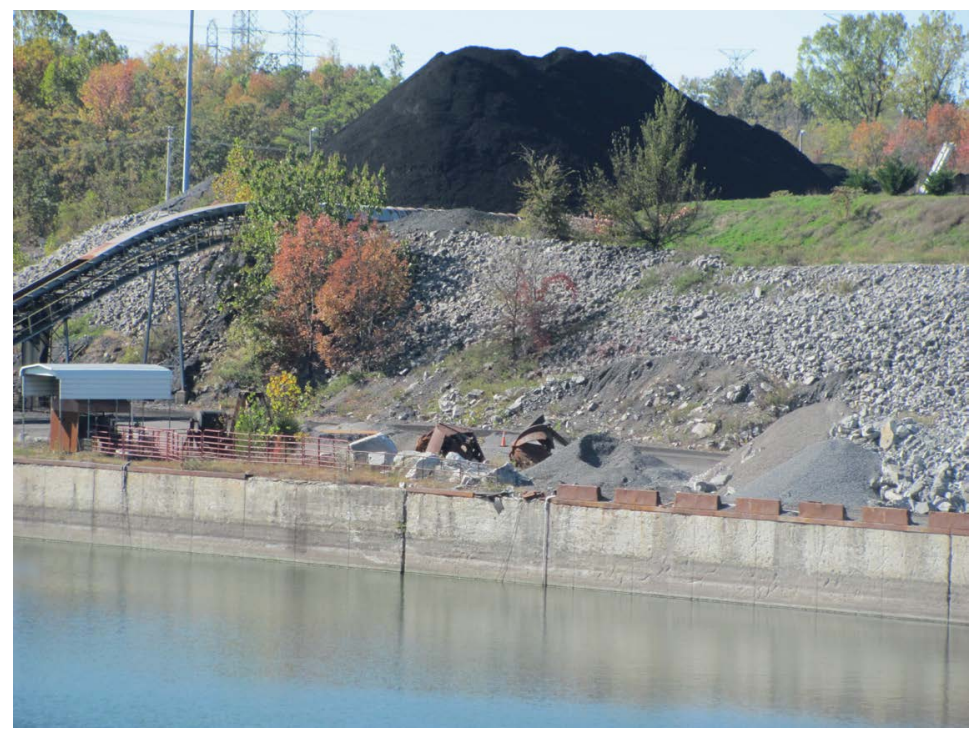

Figure 6. Coal pile ready to be loaded on a barge. This coal pile is next to the Cumberland River.

by river to lumber companies to finish for the growing construction industry. Without locks and dams, lumber rafts (up to $33 \mathrm{~m} \times 9 \mathrm{~m} \times 2.4 \mathrm{~m}$ ) had to wait for the spring rains to raise the river channel depth to float and pole their cargo downstream to markets.

After surveying the Cumberland River, USACE engineers began to identify lock and dam sites and make plans to modernize the river for commercial navigation (Figure 3). Nashville, Tennessee (Figure 7) is located on the Cumberland River [1] which is quite narrow through the city. Construction on Lock and Dam 1 located upstream from Nashville, Tennessee was begun in 1888. A few years later Lock and Dam A at Harpeth Shoals was authorized by Congress. By the early 1900s, eight stone or concrete and timber dams were built above Nashville 
and six below. And, by 1924, the Cumberland River's main channel depth had been increased to a minimum of $1.8 \mathrm{~m}$ from the Smithland confluence with the Ohio River (Figure 8) upstream to Burnside, Kentucky. New technologies in powering towboats replaced steamboats with gasoline and diesel engines enabling raw and finished materials to be moved more quickly up and downstream to manufacturing plants and consumers. Simultaneously railroad construction accelerated and expanded commercial transportation throughout the U.S. This growing network of rail and river transport provided complementary and competitive options for moving freight, and fueled the industrialization of the nation in the twentieth century. There are 6 lock and dams on the Cumberland River including Old Hickory Lock and Dam and Cordell Hull (Figures 9-11). Navigation Locks and Dam east of between Cheatham Lake and Cumberland Lake.

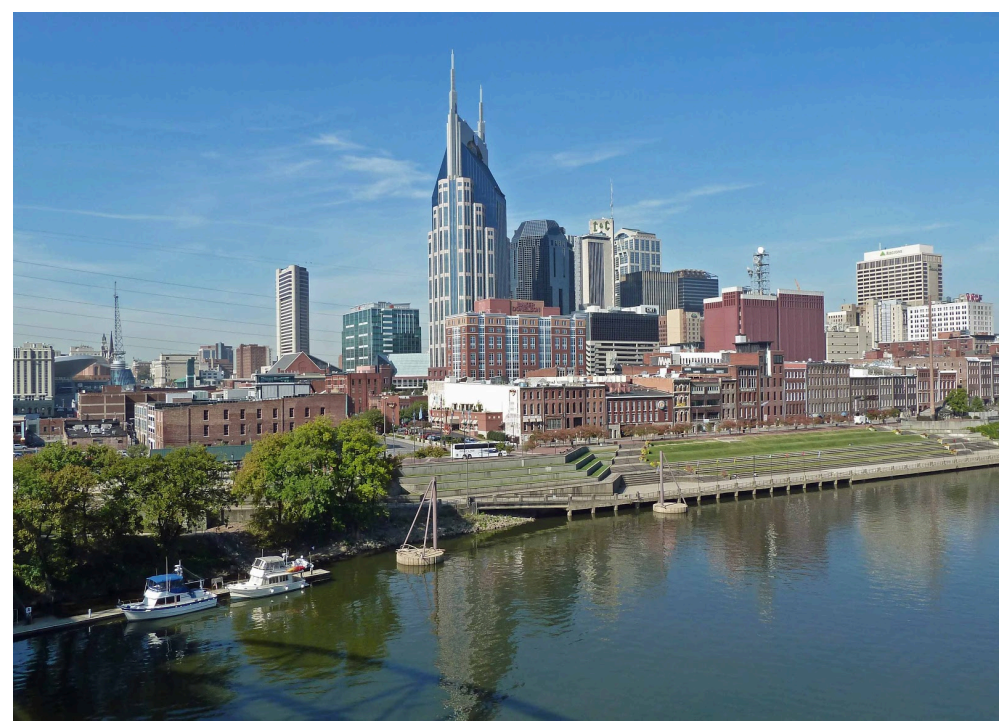

Figure 7. The Cumberland River at Nashville.

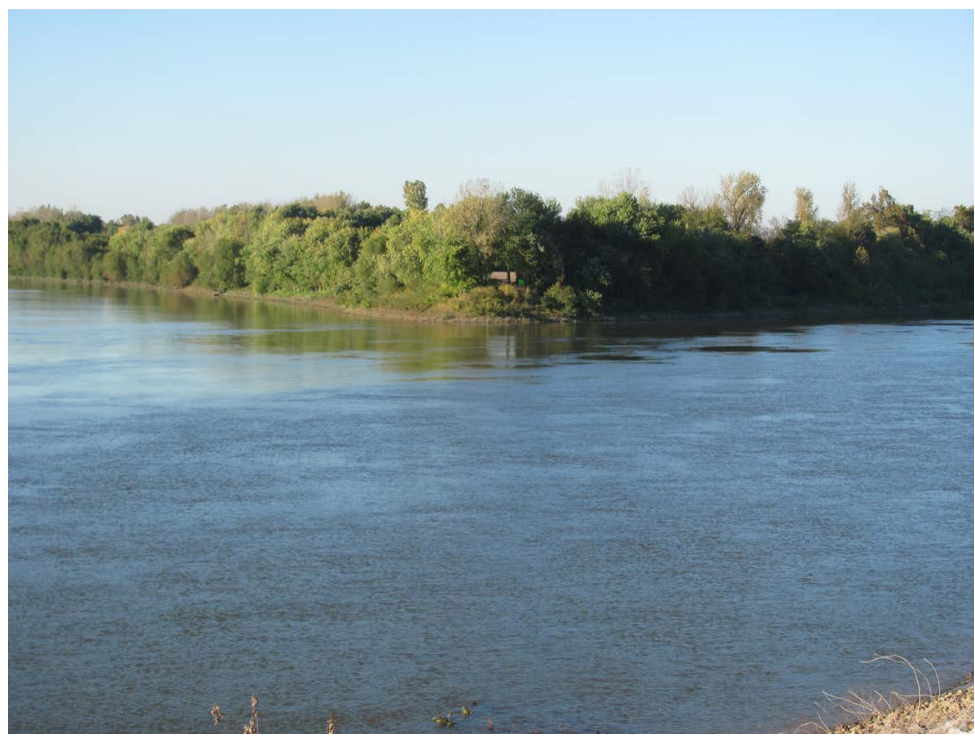

Figure 8. Picture of the Cumberland and Ohio Confluence at Smithland. 


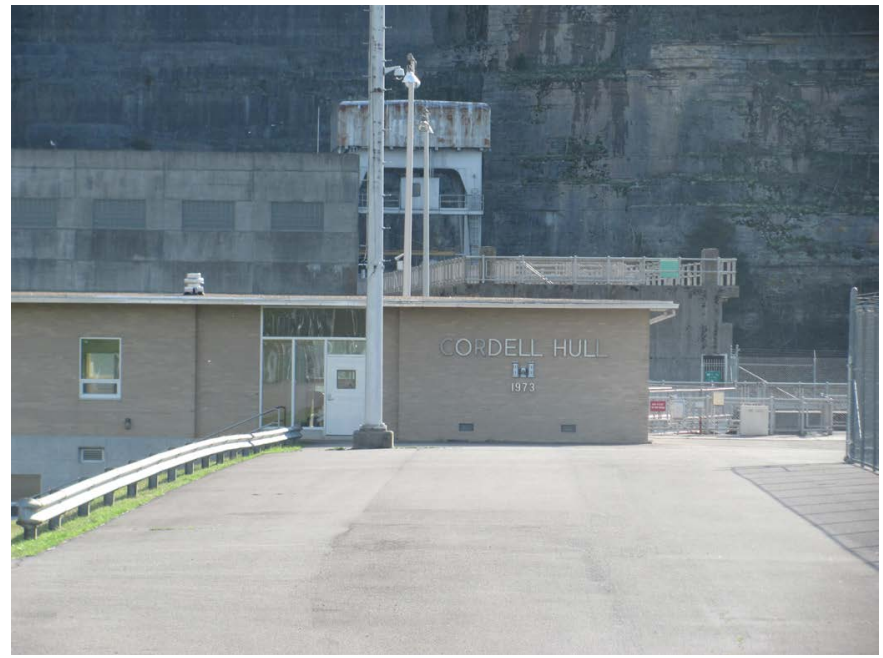

Figure 9. The Cordel Hull name on the lock and dam facilities.

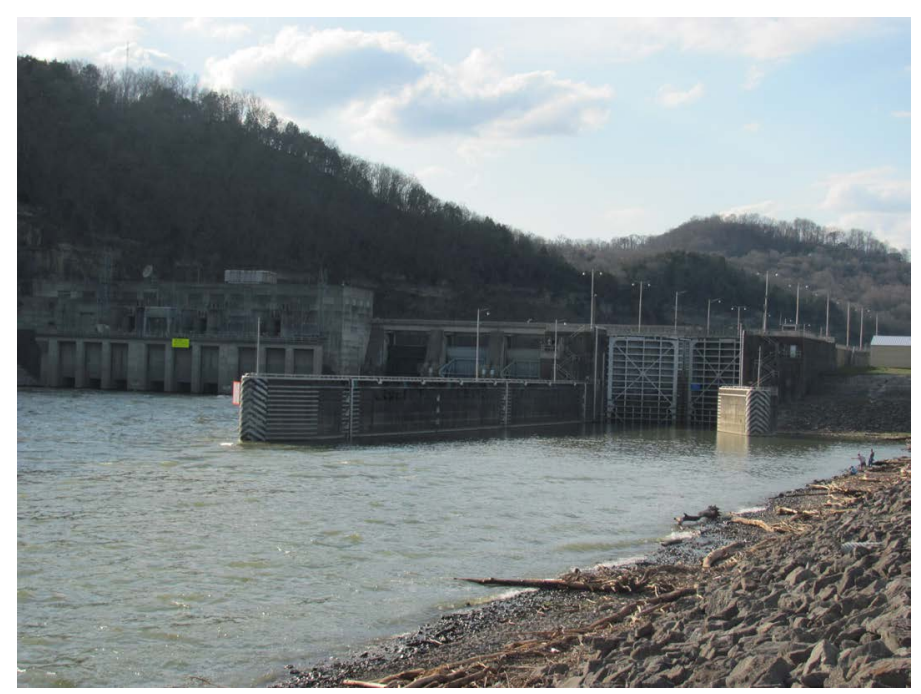

Figure 10. The Cordel Hull lock and dam on the Cumberland River.

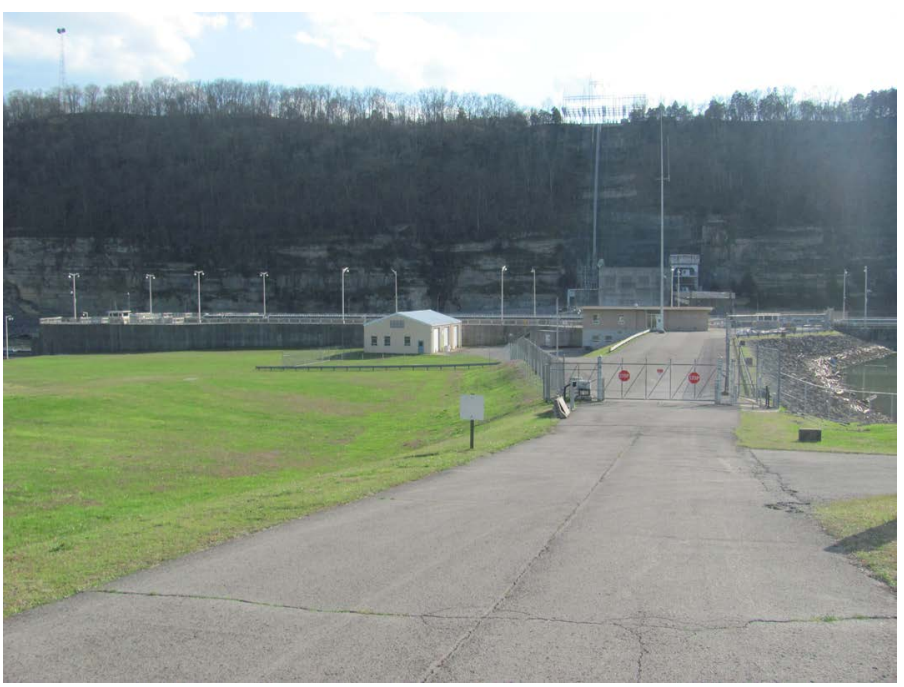

Figure 11. Cordel Hull from distance with the high vertical valley wall in the background. 
The USACE selected sites in 1936 for building four reservoirs on the Cumberland and its tributaries: Wolf Creek on the upper Cumberland (1952), Dale Hollow on Obey (1948), Center Hill on Caney Fork (1951) and Stewarts Ferry (1968) on Stones River. The Wolf Creek Dam was designed to manage the upper Cumberland River snow melt and drainage from the mountains of Kentucky to control flooding and create hydroelectricity [1]. Lake Cumberland, the $160 \mathrm{~km}$ long reservoir behind the dam has an average depth of $27.4 \mathrm{~m}$ and the capacity to hold $7500 \mathrm{~km}^{3}$ of water which can be strategically released to manage downriver flooding and for increasing the navigation channel depth during droughts. The $2020 \mathrm{~km}$ shoreline and 20,600 ha lake has become a tourist destination for fishing, houseboats, and other types of recreational boating. Two additional reservoirs were also built, the Cheatham near Ashland City (1959) and the Barkley in Western Kentucky (1966) for hydropower and flood control. In total, eight dams controlled the river from Burnside, Kentucky to Ohio River by the 1970s.

Heavy rainfall over the Cumberland River Basin during the night of January 1, 1937 averaged $6.3 \mathrm{~cm}$ with several stations reporting in excess of $10 \mathrm{~cm}$ [2]. It continued to rain and on January $2^{\text {nd }}$ flood warnings on the rising Cumberland River were issued from Burnside, Kentucky to Nashville, Tennessee. Twenty-five successive days of rain over the Ohio River Valley (Figure 12) created one of the greatest floods of record in 1937. The $1107 \mathrm{~km}$ Cumberland River, one of the three largest tributaries of the Ohio River was a major source of flooding as it drained over $46,620 \mathrm{~km}^{2}$ of upstream lands and poured into the Ohio River at Smithland, Kentucky (Figure 8). A 20 m crest at Clarksville, Tennessee River set a record, exceeding the 1927 flood crest by $1.68 \mathrm{~m}$. Downstream at Eddyville, Kentucky the January 1937 crest marked an all-time record at $23.4 \mathrm{~m}$.

Twenty-six years later, the Barkley Dam on the Cumberland (Figure 13) was constructed east of the Kentucky Dam on the Tennessee River to reduce Ohio River flooding and control early snow melt and precipitation flowing from the Appalachian Mountain headwaters of the Cumberland River (Figure 4). Named after Senator Alben W. Barkley (Figure 14) who was instrumental in passing the 1938 Flood Control Act, the Barkley Dam and Reservoir is a critical component of the USACE and Tennessee Valley Authority (TVA) flood control and navigation plan for the Mississippi River Basin [3]. A string of locks and dams upriver from the Barkley Dam protect Clarksville, Nashville and other small towns from Cumberland River internal flooding and enable river transportation from Lake Cumberland, Kentucky to the Ohio and Mississippi rivers all the way to the Gulf of Mexico. Although the construction of Barkley Lake displaced 4400 people from their homes along the Cumberland River, it was part of a rural development strategy for southern Kentucky and north central Tennessee by TVA to provide power (Figure 15), employment, and economic growth for the region.

The primary objectives of the paper are: 1) to document how the landscape and geological resources of the Cumberland River have contributed to the successful water resource and economic development of a historic region in North 


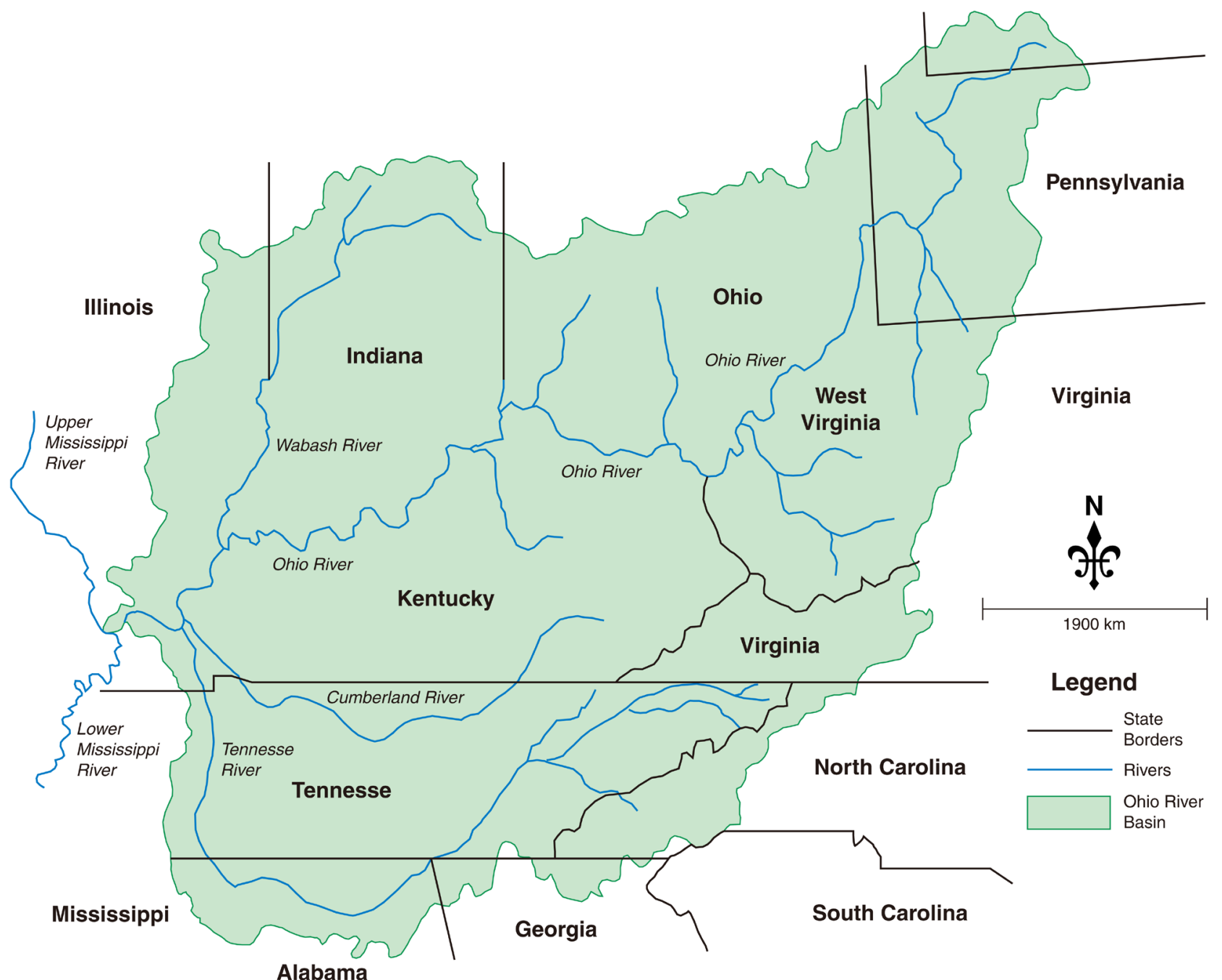

Figure 12. The Ohio, Cumberland, Tennessee, Wabash Rivers in the Ohio River valley. Map by Mic Greenberg.

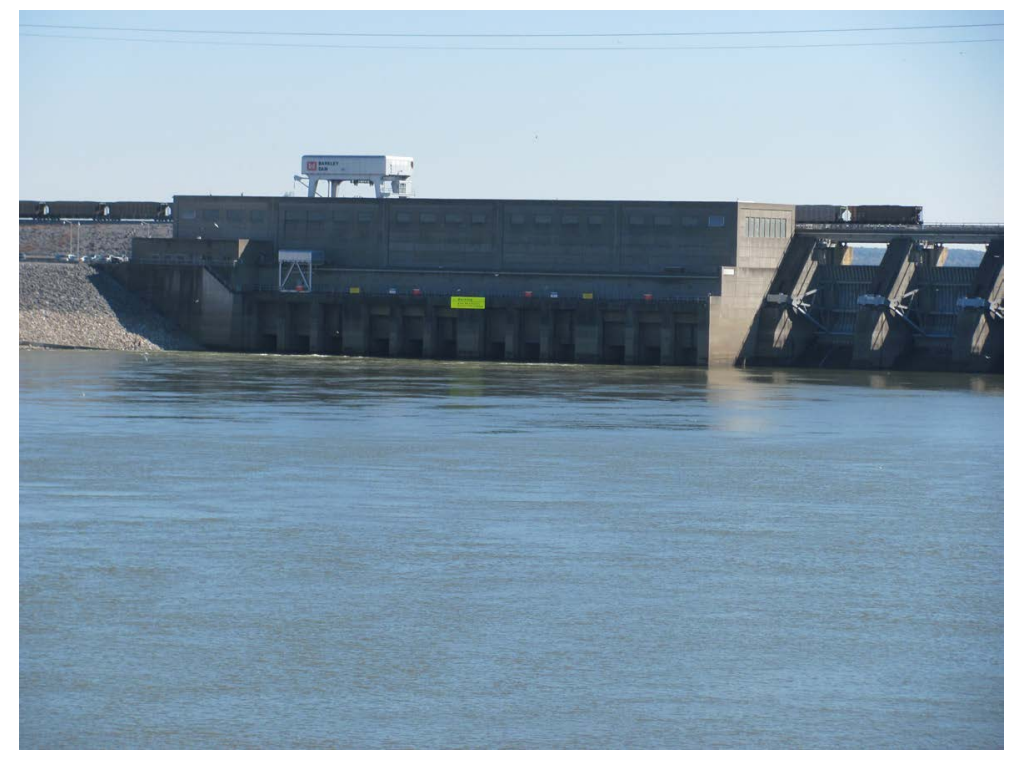

Figure 13. The Barkley dam with name on the Cumberland River. 


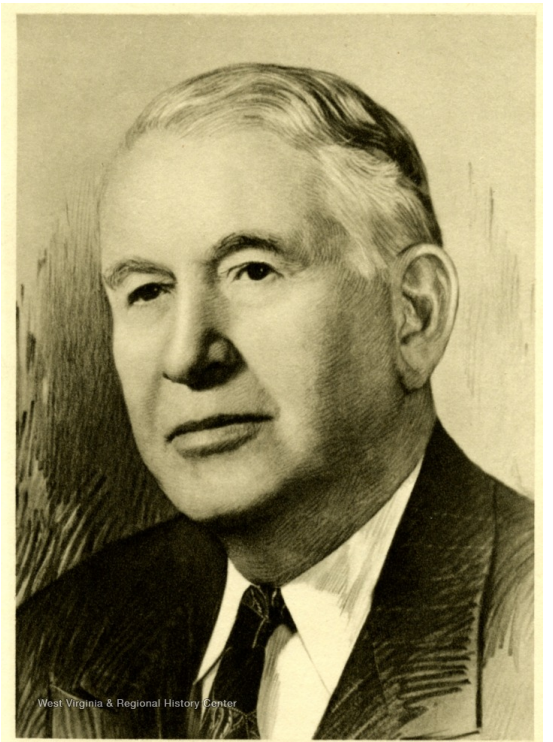

Figure 14. The Barkley Dam and Lake was named after Senator Alben W. Barkley who was instrumental in passing the 1938 Flood Control Act.

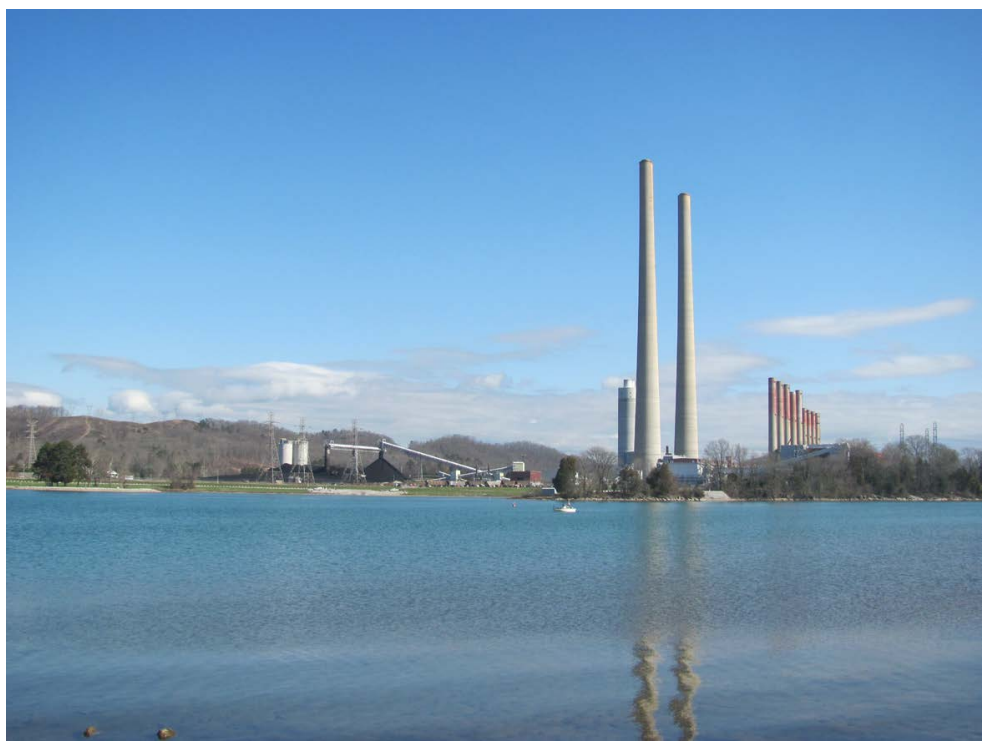

Figure 15. Smoke stacks power plant on the Cumberland River.

America, 2) to identify the natural and environmental resource risks to the Cumberland River basin, 3) create a Cumberland River regional trail system, similar to the Tennessee River regional trail systems, with more community access points along the Cumberland River pathway, and 4) create generations of people who care about the environmental stewardship and protection of the river and landscape resources.

\section{Site Location}

\subsection{Ancient Ohio and Cumberland River Valleys}

Millions of years ago the ancient Cumberland River carried snowmelt and preci- 
pitation runoff water from the Appalachian uplands westward and drained into the ancient Ohio River on its way through Southern Illinois (Figure 16) and the confluence with ancient Mississippi River [4]. The White River to the north and the Cumberland flowing from the south were major tributaries of the ancient Ohio River while the Wabash and Vermillion rivers were blocked by glacial ice dams and drained northward into the ancient Teays River Valley. The ancient Tennessee River (west of the ancient Cumberland River) ran in the modern day Ohio River channel and confluenced directly with the ancient Mississippi River south of modern day city of Cairo. Seismic activity and glacial melt water cut through the land bridge (Figure 16) [5] and the ancient Cumberland, White, Tennessee and Ohio Rivers combined to create the current Ohio River which was formerly the ancient Tennessee River channel. About 12,000 to 15,000 years ago at the end of the glacial period these combined rivers redirected their flows into the current Ohio River channel leaving the ancient Ohio River valley in southern Illinois (modern day Cache River and Bay Creek valleys) (Figure 17) without a major river and only local drainage.

\subsection{Federal Response to Flood of 1936-1937: The Barkley Dam, Reservoir and Barkley Canal}

A series of storms after Christmas 1936 dumped heavy precipitation over the Ohio River Valley and its tributaries as warm moist air from the Gulf of Mexico collided with dry cold Artic air over a 26 day period extending into late January

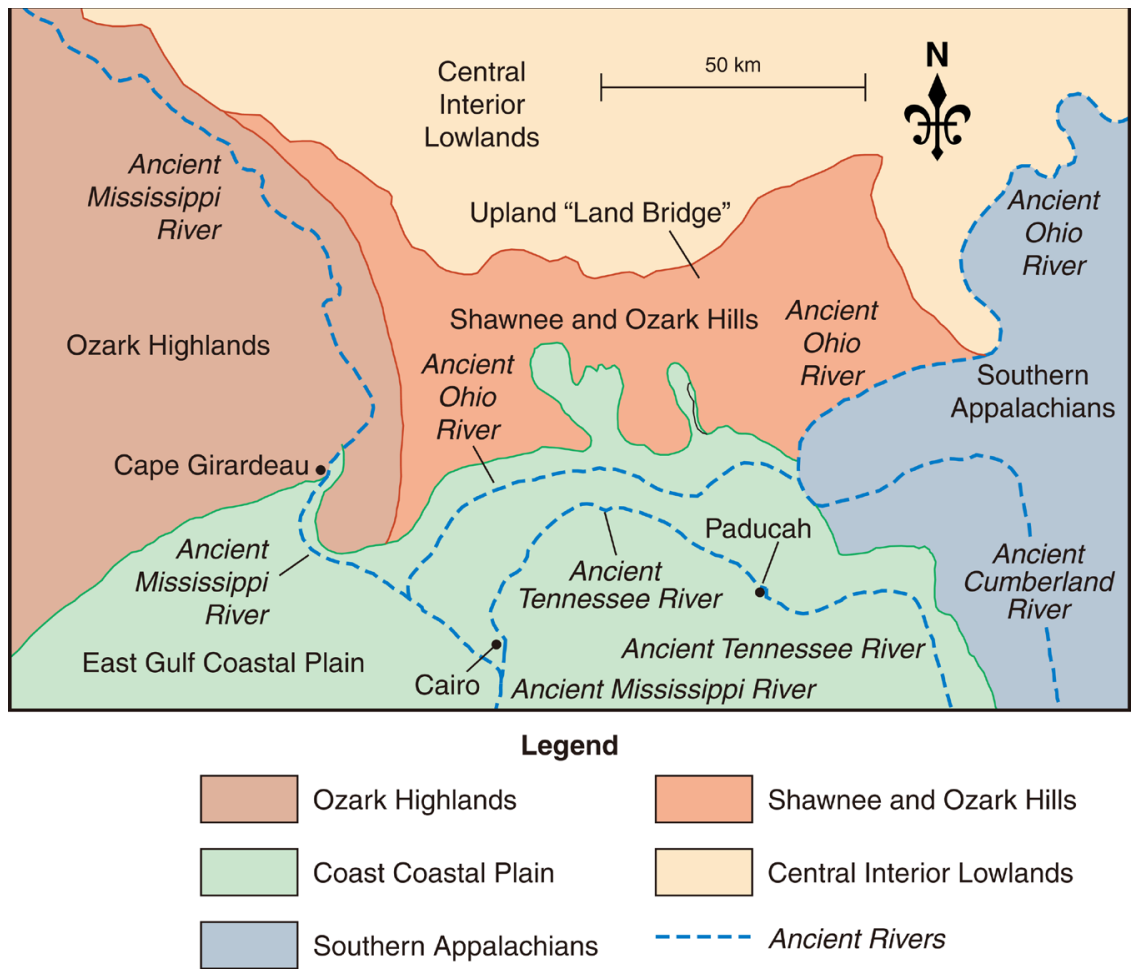

Figure 16. River drainage patterns including the Ancient Cumberland, Ancient Ohio and Ancient Tennessee rivers and the land bridge. Map by Mic Greenberg. 


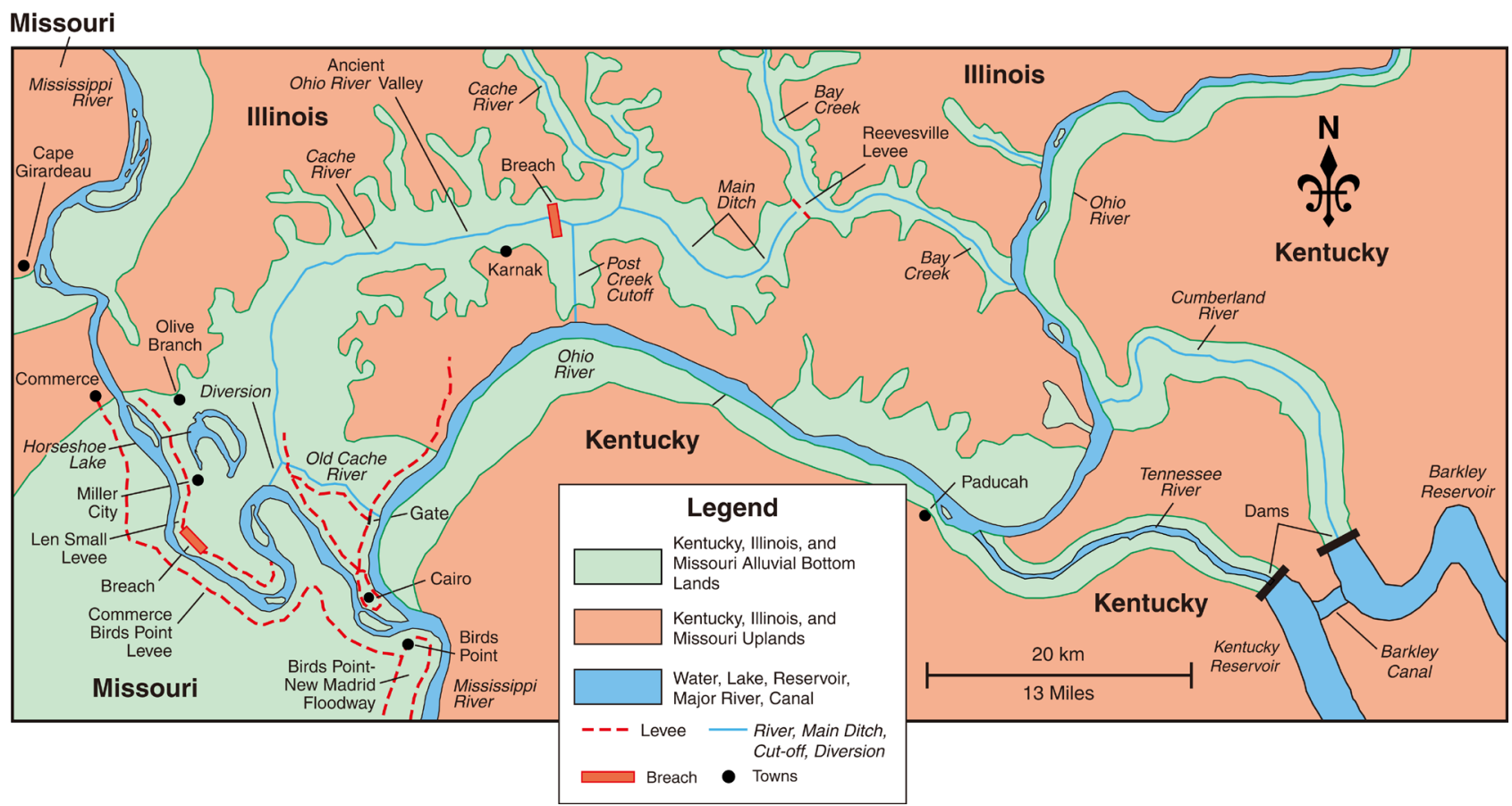

Figure 17. The Kentucky Reservoir on the Tennessee River and the Barkley Reservoir on the Cumberland River flow northwest into the Ohio River. Published with copyright permission from Book Editor of Soil and Water Conservation Society [12]. Map by Mic Greenberg.

1937. The January crests on the Cumberland River ran from Burnside, Kentucky at $16.6 \mathrm{~m}$; to Nashville at $16.4 \mathrm{~m}$, to Eddyville, Kentucky at $23.4 \mathrm{~m}$ making it one of the worst floods the region had ever experienced [2]. Kentucky and Tennessee were not alone. This sequence of storms resulted in one of the most destructive flood disasters ever recorded along the Ohio River and the lower Mississippi River. The Flood Control Act of 1938 led to the construction of scores of upstream dams and reservoirs on tributaries throughout the Ohio River valley (Figure 8). The TVA system developed a series of lakes. Wolf Creek Dam was built in 1952 and created Lake Cumberland (Figure 1) for flood control and electric power. Two power dams were built on the tributaries the Dale Hollow Dam (1953) on Obey River and the Center Hill Dam (1951) on Caney Fork (Figure 18). The Cheatcham Dam and Barkley (1966) dams were built on the main stem of the Cumberland River.

The Kentucky Dam (Figure 19) on the Tennessee River, $35 \mathrm{~km}$ upstream from Paducah was started in 1938 and completed in 1944 [5]. The placement of TVA's Kentucky Dam on the Tennessee River and the USACE's Barkley Dam on the Cumberland River created a recreational area called the Land Between the Lakes. Between 1958 and 1963 about 1400 families in western Kentucky and Tennessee were moved from their homes along the Cumberland River and the upland ridge between the Tennessee River and the Cumberland River to make way for a second large dam and reservoir, the Barkley [6]. The area between the Kentucky Lake and the Barkley Lake became known as the Land Between the Lakes. 


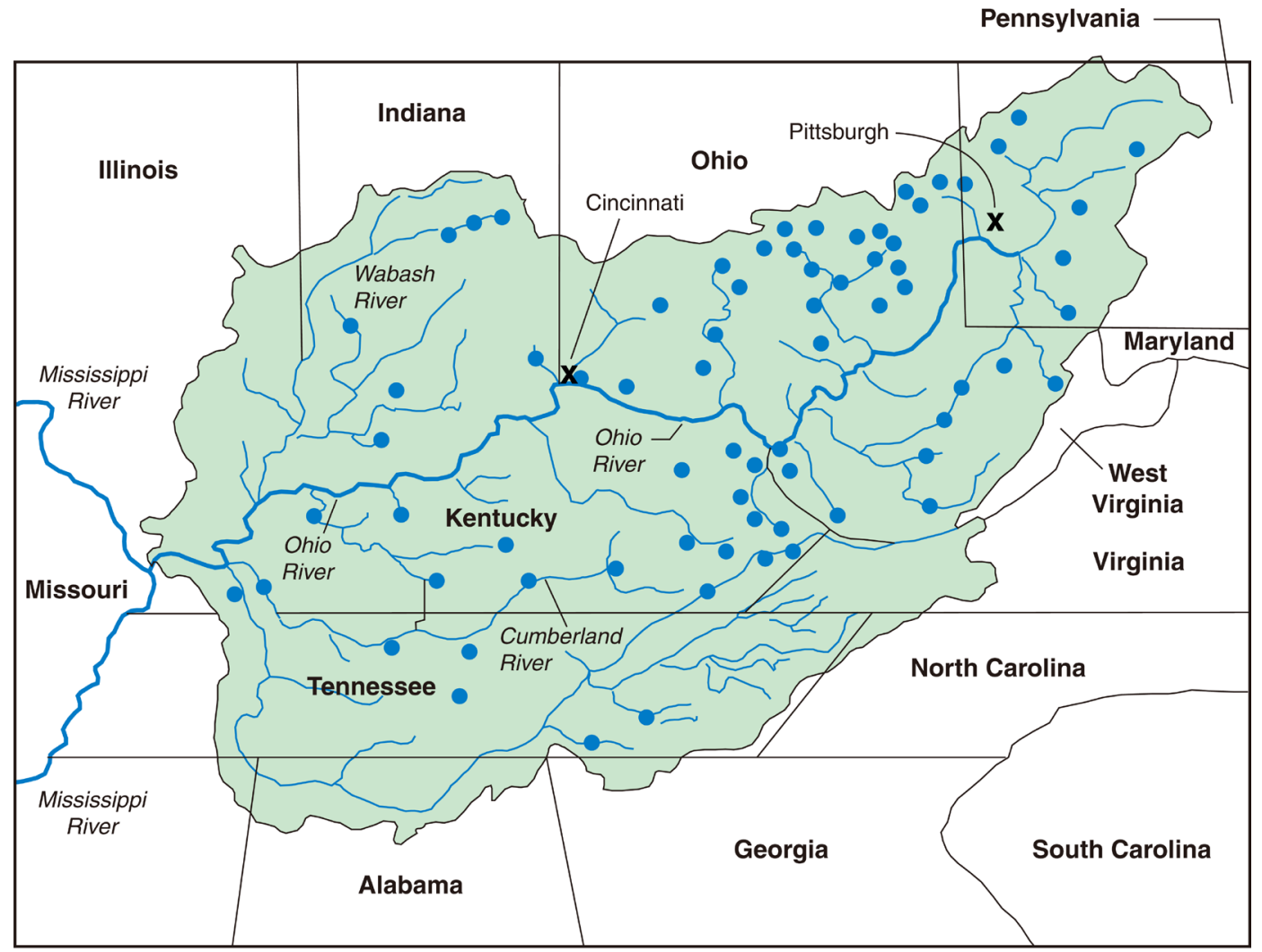

Ohio River Basin Reservoirs

Figure 18. Ohio River valley reservoirs. Map by Mic Greenberg.

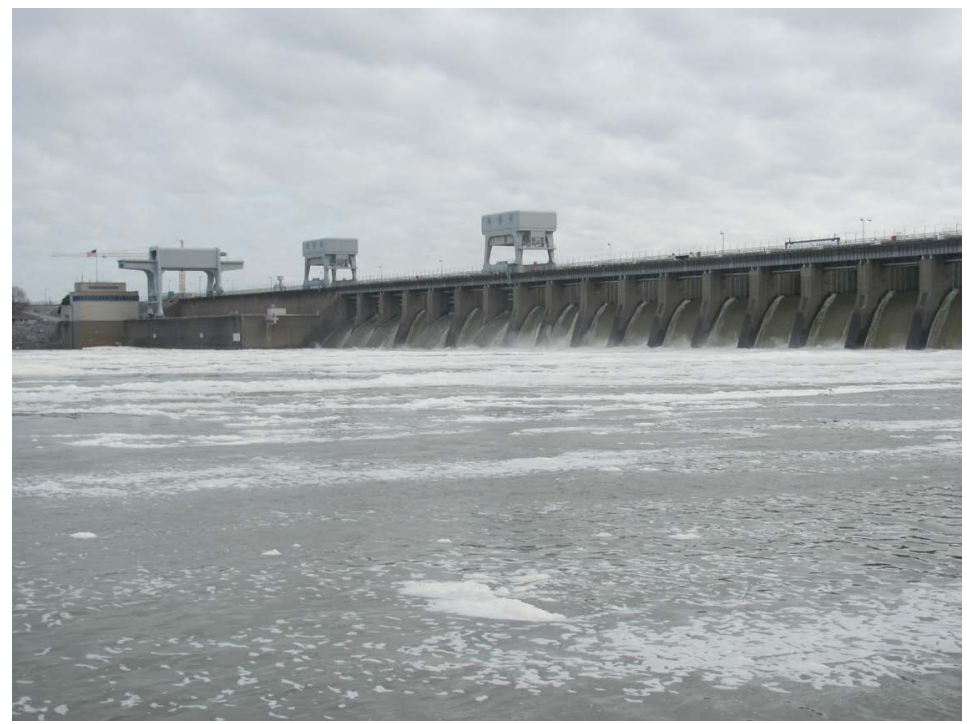

Figure 19. Wide Kentucky dam with all gates open and releasing water after an Ohio River flooding event in 2016.

The Barkley Dam was constructed by the USACE across Cumberland River and completed in 1966. The Dam (Figure 13) is $48 \mathrm{~m}$ high and can impound a maximum of 25,681 ha-m in Lake Barkley, a 23,000 ha reservoir in Kentucky. 
Lake Barkley is $216 \mathrm{~km}$ long with a shoreline of $1616 \mathrm{~km}$. The lake is maintained at different levels throughout the year for flood control and navigation purposes. The summer pool is $109 \mathrm{~m}$ above sea level and the winter pool is $107 \mathrm{~m}$. The lakes water surface area varies from 23,400 ha at summer pool to 18,300 ha at winter pool.

The flood of 2011 provided a strenuous test of the USACE Mississippi River Basin flood management strategy of levees, floodwalls, floodways, and upstream reservoirs. Early snowmelt and an extended period of heavy spring rains in the Ohio River Basin and Upper Mississippi River basin strained the floodwall and levee infrastructure at the Cairo, Illinois near the confluence of the Ohio and Mississippi Rivers. Under these conditions, the plan called for managing the release of water from the Kentucky and Barkley dams (Figure 13 and Figure 19) in April to reduce peak flow levels on the Ohio River. This meant flood waters from the Cumberland and Tennessee rivers would be held back to lower the Ohio River crest as it approached the confluence of the Ohio and Mississippi Rivers at Cairo.

The main problem for the Land Resource Division (LRD) managers involved the release of water from the J.P. Priest, Center Hill Lake, Dale Hollow and four other reservoirs on the Cumberland and Tennessee rivers. The Wolf Creek and Center Hill dams were undergoing critical dam safety repairs and held restrictive ratings on the Dam Safety Action Classification list. The pool elevations in the reservoirs behind the dams had been lowered substantially to prevent seepage failure. To keep the pool elevations below restricted levels, the dams were releasing maximum discharges. If the forecast of continued rain occurred in April and May of 2011 the LRD faced a difficult decision. Continuing the maximum discharge from Wolf Creek and Center Hill dams took away valuable flood storage capacity at the Kentucky and Barkley reservoirs (Figure 17). However, if more water was held back and water pressure built up too high behind the dams with restrictive ratings dam failure could turn a problem into a disaster [7].

On April $22^{\text {nd }} 2.5 \mathrm{~cm}$ to $7.5 \mathrm{~cm}$ of rain fell over most of the middle Mississippi River basin. On April 23 $3^{\text {rd }}$ the Bootheel of southeast Missouri received $7.5 \mathrm{~cm}$ to $12.5 \mathrm{~cm}$ of rain. The Weather Service provided a contingency forecast but did not release to the public [8] for fear the public might over react and these weather forecasts are not always reliable. The Weather Service predicted a Cairo gage peak range from $18.7 \mathrm{~m}$ to $15.4 \mathrm{~m}$. On April 24, 2011 the Cairo gage stood at 15 $\mathrm{cm}$ higher than the previous day forecast. As the Ohio River rushed to the Mississippi confluence, sand boils and sinkholes appeared under the floodwall and levees at Cairo. The risk to leveed cities and farmland in Kentucky, Illinois, Missouri and downriver increased as the rivers rose higher and higher and threatened to overtop the levees or breach them from river pressure. By May 2, 2011 with upstream reservoirs at capacity and local levees threatening to fail, the USACE put in use the Birds Point-New Madrid Floodway just south of the confluence. This planned induced levee breaching re-directed the Mississippi River into the flood- 
way and quickly lowered the flood crest on both rivers. However, the farmer levees, Len Small in Illinois and the Commerce farmer levee in Missouri were considerably weakened and both failed just before and just after the New Madrid Floodway was opened using TNT to blow a hole in the Birds Point levee.

\subsection{Tennessee Valley Authority}

The most dramatic change in Cumberland Valley life came from the electricity generated by USACE and TVA dams (Figure 13 and Figure 19). The TVA is the nation's largest power company. Cheap transportation along the River helped to develop the economy of the State of Tennessee. Electric lights and modern appliances made life easier and farms more productive. Electricity also drew industries into the region, providing needed jobs. The Barkley Dam (Figure 13) was created on the Cumberland River, only a few kilometers from Kentucky Dam (Figure 19). The dam was created for several purposes, but most importantly, flood control and generated hydroelectric power. Eddyville and Kuttawa, located on the Cumberland River, were often flooded by the river. USACE decided that the small locks and dams up and down the Cumberland River were not enough for flood control, so the construction of the Barkley Dam began in 1959 and was completed in 1964. These reservoirs were connected by the Barkley shipping channel (Figure 20) which helps keep the surface levels at a similar elevation. Water releases are timed to maintain the water levels in the two lakes within $0.3 \mathrm{~m}$.

\subsection{Managing Cumberland, Tennessee and Ohio Rivers in Highly Variable Climatic Conditions}

The historical levees-only strategy of the USACE resulted in construction of levees on the bottomlands along both sides of the lower Mississippi River from

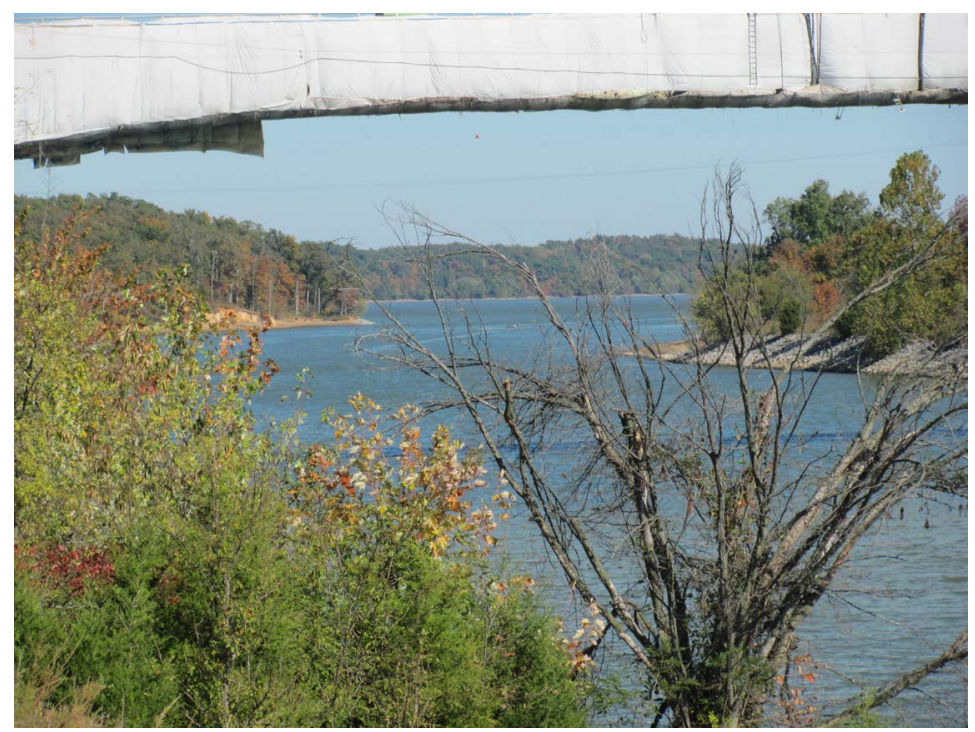

Figure 20. Barkley canal which connects Kentucky Lake to Barkley Lake. Photograph taken by Lois Wright Morton. 
Cairo, Illinois to New Orleans, Louisiana [7] [8] as a response to flood waters from both the Mississippi and Ohio rivers and their tributaries. Over the years, this strategy was modified with the creation of four separate floodways (Figure 21) in Missouri (Birds Point-New Madrid Floodway), Louisiana (West Atchafalaya Floodway), Louisiana (Bonnet Carre Spillway and Floodway) and Louisiana (Morganza Spillway and Floodway). The USACE decision to add floodways (Figure 21) was a huge shift in river management planning [7] [9]. After the flood of 1937, the USACE went from confinement to dispersion approach to flood management with the construction of upstream reservoirs. In the 1940s the Cairo confluence area benefited from the TVA construction of the Kentucky Dam on the Tennessee River and the 1960s building of the Barkley Dam (Figure 13)

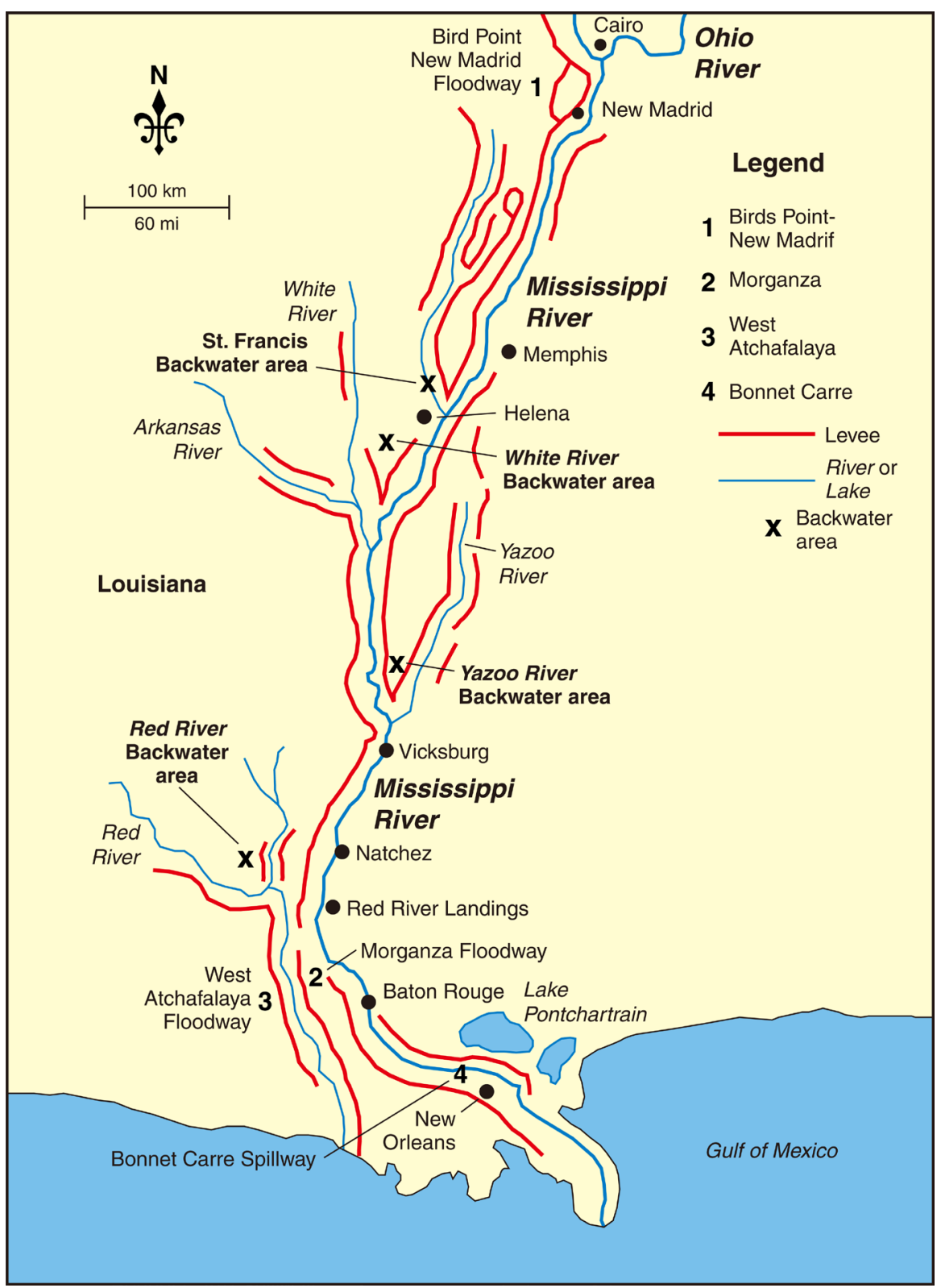

Figure 21. Lower Mississippi River floodways. Map by Mic Greenberg. 
on the Cumberland River. These lock and dam-reservoir systems improved the USACE capacity to control the fast rise of the Ohio River during spring rains and maintain water levels for navigation during dry periods.

The flood of 2011 and the drought of 2012 in the Mississippi-Ohio river basins resulted in record river crests (Figure 22) and flooding followed by near record low water levels on the lower Ohio and lower Mississippi rivers [9] [10] [11]. The Kentucky and Barkley reservoirs have the capacity to hold vast amounts of water during flooding events with pools extending through Kentucky and into the state of Tennessee. During the drought of 2012 which lasted from June 2012 through January of 2013, these reservoirs were used to discharge sufficient water to add at least $1.2 \mathrm{~m}$ to the lower Ohio River shipping channel depth and allow shipping without additional dredging. It is quite likely that shipping would have stopped or been interrupted for many months without the use of Kentucky and Barkley reservoirs.

\subsection{Land between the Lakes}

The Cumberland and Tennessee rivers flow north into the Ohio River side by

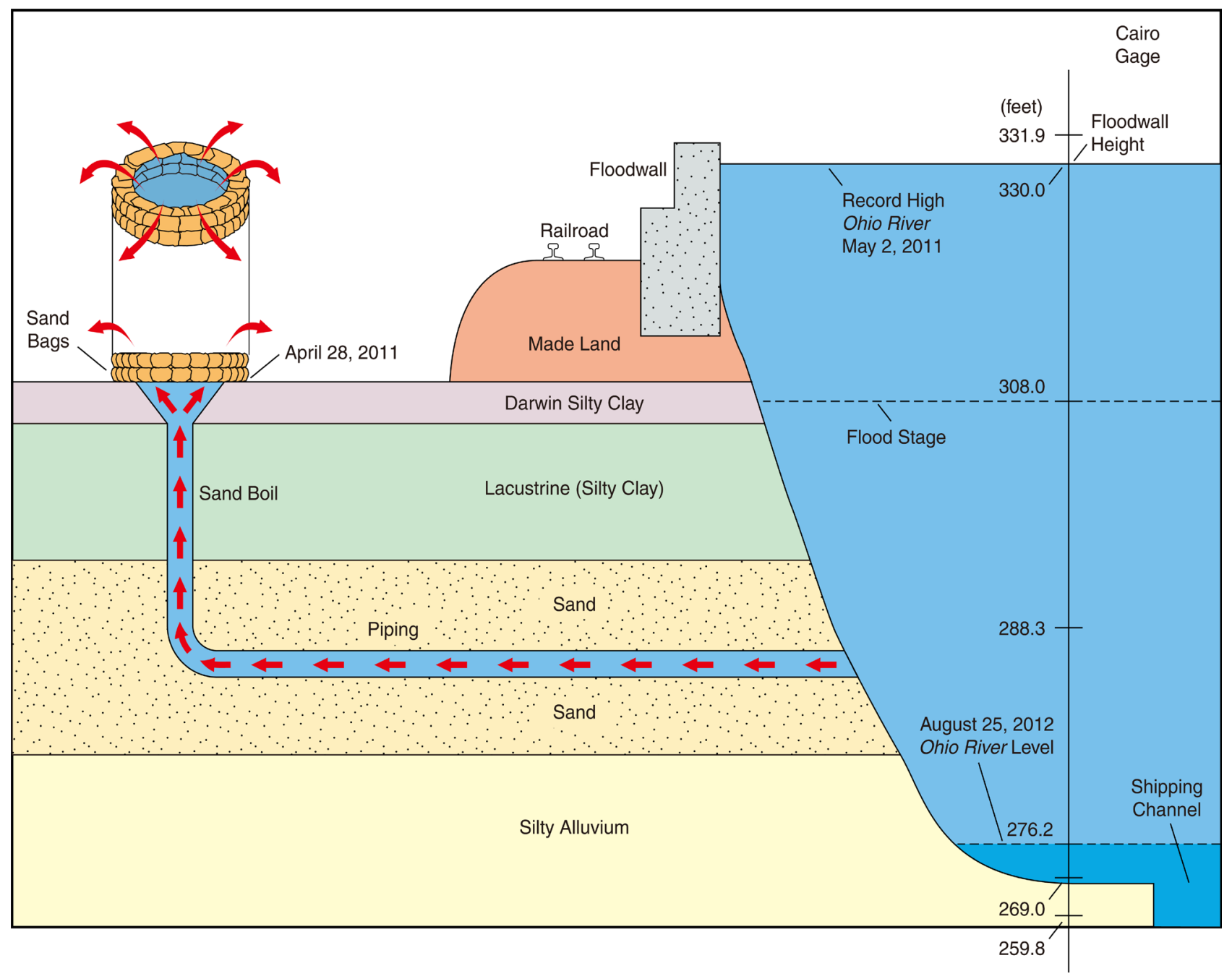

Figure 22. Record high and low Ohio River water levels in 2011 and 2012. Drawing by Mic Greenberg. 


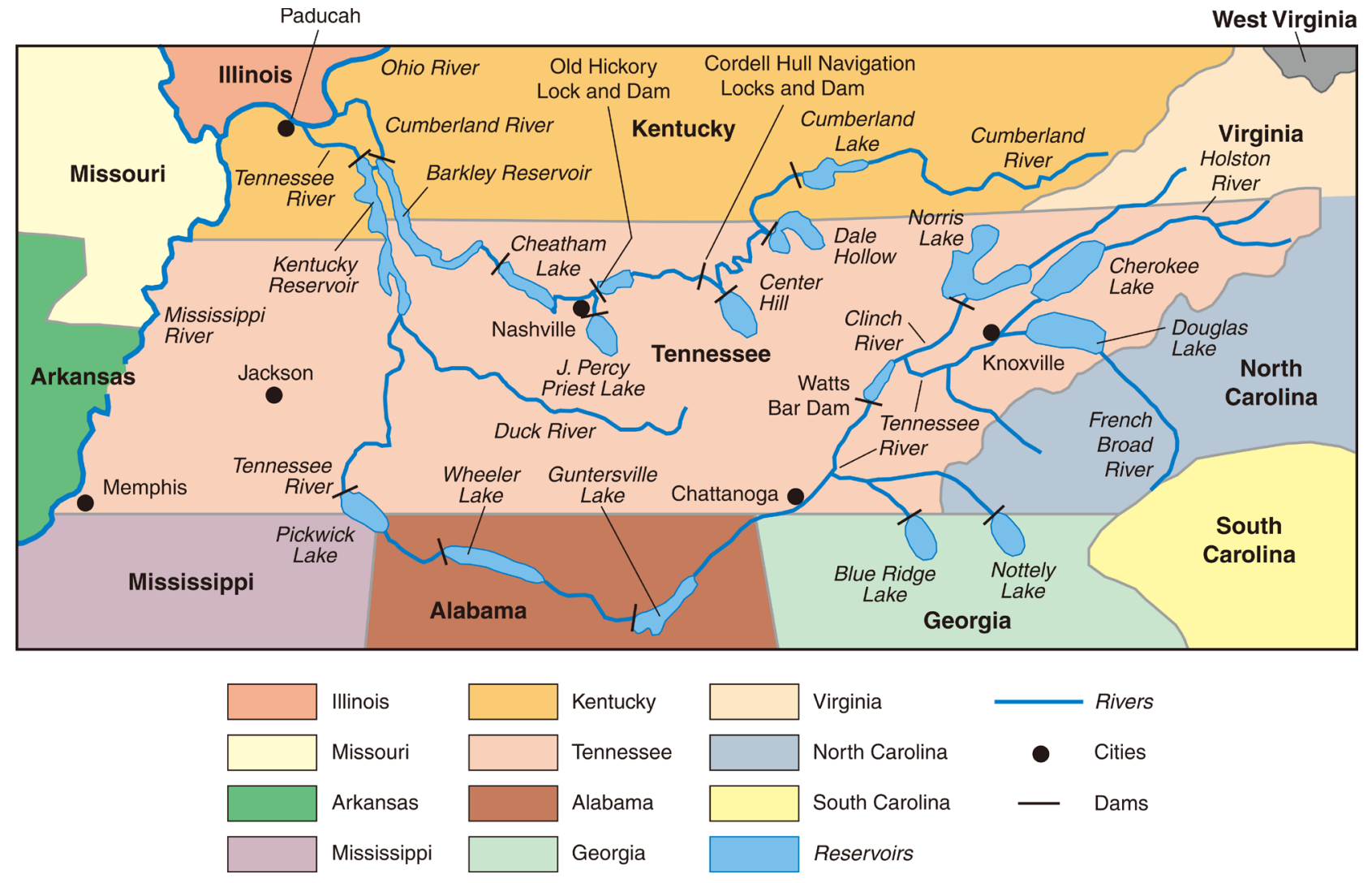

Figure 23. The Cumberland and the Tennessee Rivers headwaters begin in the Appalachian Mountains of east Kentucky and east Tennessee. Published with copyright permission from Book Editor of Soil and Water Conservation Society [12]. Map by Mic Greenberg. 


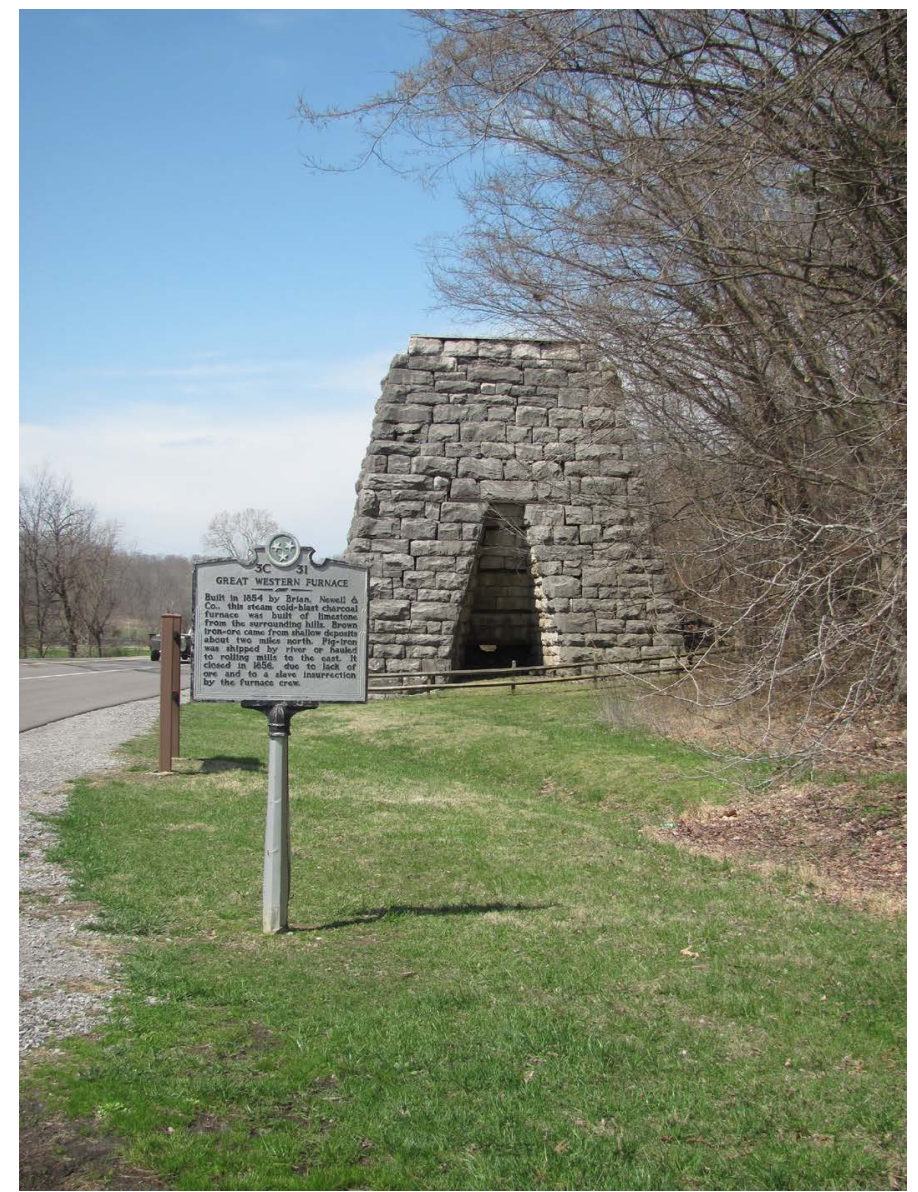

Figure 24. Great Western Furnace used in the early 1900s. Photograph taken by Lois Wright Morton.

LBL's indicate that upland oak forests and grasslands were more prevalent than they are today. In recent years, oak-grassland restoration demonstration areas have been established in the area. A tourist destination, the LBL's offers camping, hunting, fishing, off-highway vehicle riding, horseback riding and environmental education programs. Featuring "outside play" the national recreation area provides access to over $480 \mathrm{~km}$ of natural shoreline, $320 \mathrm{~km}$ of paved road and $800 \mathrm{~km}$ ) of trails.

\subsection{Mantle Rock Nature Preserve}

Located $28 \mathrm{~km}$ north of the Cumberland and Ohio Rivers confluence lies an area rich in biodiversity, archeology, and historical value. Owned and managed by The Nature Conservancy, Mantle Rock Nature Preserve holds a significant rock formation. The sandstone bridge is $9.4 \mathrm{~m}$ high and $57.3 \mathrm{~m}$ long. In 2004, the National Park Service certified the site as part of the Trail of Tears National Historic Trail. In 2010, The Nature Conservancy enhanced the site with interpretive signage and well-maintained hiking trails. Native warm season grasses and oakhickory dominated forest are in abundance as well as sandstone glades. A wide variety of songbirds, reptiles, and mammals are present across the preserve. In 
addition, there are clear running bolder lined streams on the preserve. The site has become a popular hiking and nature experience destination since the upgrades by The Nature Conservancy and its partners (personal communication from Shelly Morris, The Nature Conservancy).

\section{Conclusions}

Since the construction of the Barkley Dam on Cumberland River in 1960s and the Kentucky Dam on the Tennessee River (Figure 23) in the 1940s the USACE has had the ability to store and release water during major droughts such as 2012 to maintain a minimum $2 \mathrm{~m}$ depth of river water above the $2.7 \mathrm{~m}$ Ohio River shipping channel [4]. The Kentucky and Barkley reservoir water releases also increases the flow in the lower Mississippi River. The need for Ohio and Lower Mississippi River dredging was reduced during the 2012 drought. The New Madrid floodway did not have to be used during flooding events between the 1940s and 2011. This reservoir storage strategy worked until the record flood of 2011. With the Barkley and Kentucky reservoirs at full capacity, USACE was forced to release excess water. Management of the Ohio and Mississippi river landscapes continues to be a challenge for the USACE as the frequency of extreme weather years, such as the flood of 2011 and the drought of 2012, is increasing [12].

Public and private levee systems may not be robust enough to address flooding risk to agriculture under changing climate conditions. Of concern are levee protected riverine bottomlands with intensive agricultural uses and diminished wetland systems that give resilience to floodplain hydrologic functions. In the United States natural and induced levee breaching has caused soil damage, loss of agricultural productivity, and public tension among agricultural landowners, urban residents, and environmental interests. Risk management and adaptive capacity of this human natural system could be improved by assessments of: 1) soil damage and 2) stakeholder values, fears, and knowledge about the riverine bottomland agroecosystem. Effective management beyond confinement-dispersion strategies for future unknown risks and catastrophes will need new strategies beyond the current levee, floodway, lock and dams and reservoir structures represent [9] [13] [14].

A Cumberland River regional trail system, similar to the Tennessee River regional trail system under development, is needed to promote recreational tourism and increase use of the Cumberland River and basin. The goal would be to create generations of people who care about the Cumberland River and are willing to provide environmental stewardship of the watershed resources and protect the river for future generations.

\section{Acknowledgements}

Published with funding support from USDA, NIFA, Water Division and Department of NRES and with the approval of the Director of the Illinois Office of Research, College of Agricultural, Consumer, and Environmental Science, University of Illinois, Urbana, Illinois. John Crevillo fact checked and edited this article. 


\section{Conflicts of Interest}

The author declares no conflicts of interest regarding the publication of this paper.

\section{References}

[1] Wikipedia (2020) The Tennessee River. The Free Encyclopedia. Wikimedia Foundation, San Francisco.

[2] Williamson, R.M. (1937) Cumberland River and Tributaries. Monthly Weather Review, 65, 81. https://doi.org/10.1175/1520-0493(1937)65<81a:CRAT>2.0.CO;2

[3] Tennessee Valley Authority (1951) The Kentucky Project: A Comprehensive Report on Planning, Design, Construction and Initial Operations of the Kentucky Project. Tech. Report No. 13, U.S. Gov. Printing Office, Washington DC.

[4] Morton, L.W. and Olson, K.R. (2019) Securing the Nation's Infrastructure: The Ohio River. Journal of Soil and Water Conservation, 74, 5A-11A.

https://doi.org/10.2489/jswc.74.1.5A

[5] Olson, K.R. (2020) Tennessee Stewardship and Protection: The Tennessee River Line Trail Project and Partnerships. Journal of Water Resource and Protection, 12, 1053-1076. https://doi.org/10.4236/jwarp.2020.1212063

[6] Golden Pond Visitor Center Exhibits (2014) Land Between the Lakes National Recreation Area. 22 October 2014.

[7] Camillo, C.A. (2012) Divine Providence: The 2011 Flood in Mississippi River and Tributaries Project. Mississippi River Commission, Vicksburg, Mississippi.

[8] Barry, J.M. (1997) Rising Tide: The Great Mississippi Flood of 1927 and How It Changed America. Simon \& Schuster, New York.

[9] Morton, L.W. and Olson, K.R. (2014) Addressing Soil Degradation and Flood Risk Decision Making in Levee Protected Agricultural Lands under Increasingly Variable Climate Conditions. Journal of Environmental Protection, 5, 1220-1234. https://doi.org/10.4236/jep.2014.512117

[10] Olson, K.R. and Morton, L.W. (2012) The Impacts of 2011 Induced Levee Breaches on Agricultural Lands of Mississippi River Valley. Journal of Soil and Water Conservation, 67, 5A-10A. https://doi.org/10.2489/jswc.67.1.5A

[11] Olson, K.R. and Morton, L.W. (2012) The Effects of 2011 Ohio and Mississippi River Valley Flooding on Cairo, Illinois, Area. Journal of Soil and Water Conservation, 67, 42A-46A. https://doi.org/10.2489/jswc.67.2.42A

[12] Olson, K.R. and Morton, L.W. (2016) Managing the Mississippi and Ohio River Landscapes. Book Division, Soil and Water Conservation Society.

[13] Park, J., Seager, T.P., Rao, P.S.C., Convertino, M. and Linkov, I. (2013) Integrating Risk and Resilience Approaches to Catastrophe Management in Engineering Systems. Risk Analysis, 33, 356-367. https://doi.org/10.1111/j.1539-6924.2012.01885.x

[14] Kondolf, G.M. and Lopez-Llompart, P. (2020) National-Local Land-Use Conflicts in Floodways of the Mississippi River. AIMS Environmental Science, 5, 47-63. https://doi.org/10.3934/environsci.2018.1.47 